\title{
Exclusion of candidate genes from a role in cleft lip with or without cleft palate: linkage and association studies
}

\author{
G M Vintiner, K K Lo, S E Holder, R M Winter, S Malcolm
}

\begin{abstract}
Candidate genes and marker loci for cleft lip/palate $(C L / P)$ were tested using linkage analyses and association studies. Eight British families with apparent autosomal dominant inheritance of nonsyndromic $\mathbf{C L} / \mathbf{P}$ participated in the linkage analyses while the association analyses involved 61 unrelated British white people with $C L / P$ and 60 controls.

The report of an association between RARA (17q21) and unrelated Australian persons with $C L / P(p=0.016)$ was not confirmed in British $\mathbf{C L} / \mathbf{P}$ persons $\left(\chi^{2}=0.954, p>0.1\right)$. There was also no evidence of linkage between RARA and the eight $C L / P$ families $(Z=-3 \cdot 211$, $\theta=0.001)$. Linkage was excluded between familial $C L / P$ and F13A1 (map position 6p24-25) with an observed maximum lod score of $Z=-2.052$ at $\theta=0.05$. No association was found between alleles at VIM (10p13) and the British $C L / P$ subjects $\left(\chi^{2}=0.110, \mathbf{p}>0.5\right)$. Multipoint analysis excluded linkage between familial $\mathrm{CL} / \mathrm{P}$ and the markers D1S65 and D1S58 which flank the Van der Woude syndrome locus with a maximum lod score of $Z=-4 \cdot 0$. This suggests that the genetic defect underlying VWS is not the same as in non-syndromic $C L / P$. There was no evidence of linkage between CRTL1 (5q15) and the eight $C L / P$ families $(Z=-3 \cdot 466$, $\theta=0.05)$.

(f Med Genet 1993;30:773-8)
\end{abstract}

Molecular Genetics Unit, Division of Biochemistry and Genetics, Institute of Child Health, 30 Guilford Street, London WC1N 1EH, UK.

G M Vintiner

K K Lo

S Malcolm

Mothercare Unit of Clinical Genetics and Fetal Medicine, Division of

Biochemistry and

Genetics, Institute of

Child Health, 30

Guilford Street,

London WCIN 1EH,

UK.

$S$ E Holder

$\mathrm{R} M$ Winter

Correspondence to

Dr Malcolm.

Received 25 January 1993. Revised version accepted 25 May 1993.
Complex segregation analysis in different racial groups with cleft lip with or without cleft palate $(\mathrm{CL} / \mathrm{P})$ have suggested that clefting is the result of the action of a major locus with reduced penetrance. ${ }^{12}$ In support of the major locus theory is the existence of families with an apparently autosomal dominant pattern of inheritance of $\mathrm{CL} / \mathbf{P}^{34}$

In an attempt to identify a putative major gene, an association analysis was carried out by Ardinger et al, ${ }^{5}$ which compared the frequency of polymorphisms at various candidate genes in an American CL/P population and a control population. An association between polymorphisms within transforming growth factoralpha (TGFA) and unrelated subjects with $\mathrm{CL} / \mathbf{P}$ was identified. This association has since been confirmed in English ${ }^{6}$ and Australian ${ }^{7}$ subjects of mainly white north European origin. The presence of the association in three different populations suggests that TGFA contributes to the development of clefting in some people. However, no evidence of linkage was found between TGFA and CL/P in families with an apparently autosomal dominant pattern of inheritance. ${ }^{89}$ This suggests that in those families, TGFA is not a gene of major effect.

A second association between unrelated Australian persons with $\mathrm{CL} / \mathbf{P}$ and the retinoic acid receptor alpha (RARA) locus has recently been reported..$^{10}$ An allele at the PstI polymorphism of RARA, map position $17 \mathrm{q} 21$, was found more commonly in subjects with $\mathrm{CL} / \mathrm{P}$ compared with controls $(p=0 \cdot 016)$. This suggests that RARA, like TGFA, may contribute to the development of clefting in some subjects. RARA also maps near to a $t(5 ; 17)(q 15 ; q 23)$ translocation which has been observed to segregate with affected members in a family with Stickler syndrome. ${ }^{11}$ Cleft palate (CP) was among the clinical features observed.

In this study, a combined linkage and association approach has been undertaken to test the reported association between RARA and $\mathrm{CL} / \mathrm{P}$ in a British population and to test other possible major genes which may be involved in $\mathrm{CL} / \mathrm{P}$.

Candidate genes were selected on the basis of map positions close to cytogenetic aberrations causing $\mathrm{CL} / \mathrm{P}$, proximity to loci known to cause syndromic $\mathrm{CL} / \mathrm{P}$, and from published linkage and association studies.

A suggestion of linkage between $\mathrm{CL} / \mathrm{P}$ and F13A1 (6p24-25) had previously been reported by Eiberg et al. ${ }^{12} \mathrm{~A}$ maximum lod score of $Z=3.66$ at $\theta=0.00$ for males and $\theta=0.26$ for females was reported. This locus was selected as a possible marker for $\mathrm{CL} / \mathrm{P}$ and was tested in a linkage analysis with the eight $\mathrm{CL} / \mathbf{P}$ families.

VIM, map position $10 \mathrm{p} 13$, is present in the medial cell edge during palate fusion ${ }^{13}$ and also maps near to the translocation breakpoint in two subjects with non-syndromic $\mathrm{CL} / \mathbf{P} .{ }^{14}$ The karyotype of one subject was $46, X Y, t(2 ; 10)(q 53 ; p 13)$ while the other was $46, \mathrm{XY}, \mathrm{t}(10 ; 14)(\mathrm{p} 13 ; \mathrm{q} 24)$. Its potential as a candidate was tested in an association analysis with the unrelated $\mathrm{CL} / \mathrm{P}$ subjects.

D1S65 and D1S58 were selected as markers for $1 \mathrm{q}$ based on the placement of a locus for Van der Woude syndrome (VWS) in the 1q3242 region. ${ }^{15}$ VWS is an autosomal dominant disorder and is characterised by the presence of $\mathrm{CL} / \mathrm{P}, \mathrm{CP}$, and lip pits. Fusion of lip pits is thought to occur at the same time as fusion of the lip and palate, ${ }^{16}$ so the molecular defect underlying this disorder may also be involved 
in non-syndromic clefting. D1S65 and D1S58 which flank the VWS locus ${ }^{15}$ were used as markers in a multipoint analysis involving the eight CL/P families.

CRTL1, map position $5 \mathrm{q} 15,{ }^{17}$ is responsible for linking proteoglycan aggregates which are found in cartilage ${ }^{18}$ and maps near to the other translocation breakpoint observed to segregate with affected members in a family with Stickler syndrome. ${ }^{11}$ CRTLl was tested as candidate for $C L / P$ in a linkage analysis with the eight $\mathrm{CL} / \mathrm{P}$ families.

\section{Materials}

PEDIGREE INFORMATION

Eight white British families with an apparently autosomal dominant pattern of inheritance of $\mathrm{CL} / \mathrm{P}$ were analysed for linkage. Clinical details of all eight families have been reported previously. ${ }^{8}$ Chromosome analysis was carried out on an affected subject from each of the families. All karyotypes were normal.

\section{ASSOCIATION STUDY INFORMATION}

Sixty-one unrelated white British subjects with $\mathrm{CL} / \mathbf{P}$ participated in the association study with VIM and RARA. Information on the ascertainment of 57 of these subjects is outlined in Holder et $a l^{6}$ and their clinical details are outlined in table 1 . Sixty unrelated subjects were used as controls; 23 of these consisted of work colleagues while 37 were parents of children with cystic fibrosis. No clefting information was available on this latter group but they were assumed to be normal.

DNA PROBES USED

Information on the DNA probes used is outlined in table 2.

DATA ANALYSIS

Family data were prepared for analysis using LINKSYS and analysed with two point linkage using LIPED. Two different modes of inheritance and three different levels of penetrance were used in the analysis of the CL/P families.

Table 1 Distribution of types of cleft in 61 unrelated subjects.

\begin{tabular}{lcc}
\hline & No & $\%$ \\
\hline Bilateral cleft lip and palate & 18 & 29 \\
Bilateral cleft lip & 2 & 3 \\
Right sided cleft lip and palate & 7 & $11 \cdot 5$ \\
Right sided cleft lip & 7 & $11 \cdot 5$ \\
Left sided cleft lip and palate & 14 & 23 \\
Left sided cleft lip & 13 & 21 \\
\hline
\end{tabular}

Table 2 DNA probes and polymorphisms.

\begin{tabular}{llcccc}
\hline $\begin{array}{l}\text { Gene/ } \\
\text { locus }\end{array}$ & Probe & $\begin{array}{c}\text { Polymorphic } \\
\text { enzyme }\end{array}$ & $\begin{array}{c}\text { Allele } \\
\text { size }(\mathrm{kb})\end{array}$ & Freq & Ref \\
\hline D1S58 & pYNZ23 & BglI & $5 \cdot 0$ & $0 \cdot 49$ & 19 \\
D1S65 & pEKH7.4 & TaqI & $4 \cdot 2$ & $0 \cdot 51$ & 20 \\
VIM & hp4F1 & BclI & $3 \cdot 0$ & 0.53 & $0 \cdot 47$ \\
RARA & p63 & PstI & $3 \cdot 1$ & $0 \cdot 7$ & 21 \\
& & & $3 \cdot 0$ & $0 \cdot 3$ & 22 \\
\hline
\end{tabular}

Lod scores were calculated based on an autosomal dominant model of inheritance of $\mathrm{CL} / \mathrm{P}$ with a gene frequency of 0.001 and $80 \%$ penetrance. These values appeared to best reflect the inheritance pattern observed in the eight families with CL/P. Lod scores were also calculated with autosomal dominant inheritance but with a level of penetrance set at $28 \%$. This was obtained by averaging the separate penetrances which were set for males and females in an analysis of American $\mathrm{CL} / \mathrm{P}$ families by Hecht et al. ${ }^{23}$ The second model tested autosomal recessive inheritance with a gene frequency of 0.035 and an average penetrance of $35 \%$. This reflected the model proposed by Chung et $a^{24}$ but the families here are largely uninformative because of their structure. For the microsatellite markers CRTL1 and F13A1, the alleles observed were assigned an equal frequency.

Multipoint linkage analysis was carried out using the LINKMAP section of LINKAGE version $5 \cdot 04$. For the association analyses, $\chi^{2}$ analysis was used to assess any difference in allele frequencies between cases and controls.

\section{Methods}

Restriction endonuclease digestion was carried out under recommended conditions (Northumbria Biologicals Ltd). The DNA was separated by electrophoresis in $0.8 \%$ agarose, denatured in $1.49 \mathrm{~mol} / 1 \mathrm{NaCl} / 0.5 \mathrm{~mol} / 1 \mathrm{NaOH}$ solution, then transferred directly to nylon transfer membranes (Hybond-N+, Amersham) in $20 \times$ SSC. Inserts were excised from their vectors and oligolabelled with ${ }^{32} \mathrm{P}$. Probes were hybridised to filters overnight at $65^{\circ} \mathrm{C}$ then washed in $0.1 \times \mathrm{SSC}, 0.1 \% \mathrm{SDS}$ at $65^{\circ} \mathrm{C}$. Filters were exposed to $x$ ray film at $-70^{\circ} \mathrm{C}$ for seven days.

MICROSATELLITE ANALYSIS

The following sequences were used for PCR amplification. CRTL1. ${ }^{25}$ A 222 to $240 \mathrm{bp}$ fragment was observed with the CRTL1 primers: 5' CCG CGT GTC CCA GCA TCT TC 3' forward primer, 5' TCC TTG GAT GAC AGA GCT CA 3' reverse primer. Conditions for amplification were: one minute at $94^{\circ} \mathrm{C}$ denaturation, one minute at $65^{\circ} \mathrm{C}$ annealing, one minute at $72^{\circ} \mathrm{C}$ extension for 30 cycles. F13A1. ${ }^{26}$ A 195 bp fragment was observed with the F13A1 primers: 5' GAG GTT GCA CTC CAG CCT TT 3' forward primer, 5' ATG CCA TGC AGA TTA GAA A 3' reverse primer. Conditions for amplification were: one minute at $94^{\circ} \mathrm{C}$ denaturation, two minutes at $55^{\circ} \mathrm{C}$ annealing, two minutes at $72^{\circ} \mathrm{C}$ extension for 27 cycles.

PCR amplification with ${ }^{32} \mathrm{P}$ incorporated in the reaction ( $1 \mu \mathrm{Ci}$ per sample) was performed on a Techne PHC-2 amplifier. The amplified fragments were loaded onto a $6 \%$ denaturing polyacrylamide gel and electrophoresed at $50 \mathrm{~W}$ for two hours. The gel was exposed overnight to $x$ ray film at $-70^{\circ} \mathrm{C}$. Fragments were sized against a sequenced $\mathrm{M} 13$ vector 
(Sequenase kit Version 2.0, United States Biochemical).

\section{Results}

CANDIDATE LOCUS RARA

The results of the association analysis between RARA and 61 unrelated British CL/P subjects are presented in tables 3 and 4 . In table 3, the allele and genotype frequencies for the PstI

Table 3 RARA allele and genotype frequencies.

\begin{tabular}{|c|c|c|c|c|c|}
\hline \multirow[t]{2}{*}{ Subject (No) } & \multicolumn{2}{|c|}{ Allele frequency } & \multicolumn{3}{|c|}{ Genotype No (\%) } \\
\hline & $\mathrm{Al}$ & A2 & AlAl & A1A2 & A2A2 \\
\hline $\begin{array}{l}\text { CL/P (61) } \\
\text { Control (60) }\end{array}$ & $\begin{array}{l}0.21 \\
0 \cdot 27\end{array}$ & $\begin{array}{l}0.79 \\
0.73\end{array}$ & $\begin{array}{l}2(3) \\
5(9)\end{array}$ & $\begin{array}{l}22(36) \\
22(36)\end{array}$ & $\begin{array}{l}37(61) \\
33(55)\end{array}$ \\
\hline
\end{tabular}

Table 4 RARA RFLP distribution and $\chi^{2}$ analysis.

\begin{tabular}{lccccc}
\hline Enzyme & Allele & $\begin{array}{c}\text { No of CL/P } \\
\text { chromosomes }\end{array}$ & $\begin{array}{c}\text { No of control } \\
\text { chromosomes }\end{array}$ & $\chi^{2}$ & $\mathrm{p}$ \\
\hline Pst I & A1 & 26 & 32 & 0.954 & $0.5>\mathrm{p}>0 \cdot 1$ \\
& A2 & 96 & 88 & & \\
\hline
\end{tabular}

Table 5 Lod scores for two point linkage of $C L / P$ and $R A R A$. Total lod scores with (1) autosomal dominant pattern of inheritance of $C L / P, 80 \%$ penetrance; (2) autosomal dominant pattern of inheritance of $C L / P$, penetrance $28 \%$; (3) autosomal recessive pattern of inheritance of $C L / P$, penetrance $35 \%$.

\begin{tabular}{lrrrrrrrr}
\hline Family & \multicolumn{7}{c}{$\theta$} \\
\cline { 2 - 9 } & \multicolumn{1}{c}{0.000} & \multicolumn{1}{c}{0.001} & \multicolumn{1}{c}{0.05} & \multicolumn{1}{c}{0.1} & \multicolumn{1}{c}{0.2} & \multicolumn{1}{c}{0.3} & 0.4 & 0.5 \\
\hline BR & 0.314 & 0.313 & 0.269 & 0.225 & 0.143 & 0.072 & 0.020 & 0.000 \\
CD & -2.796 & -2.792 & -1.683 & -1.132 & -0.589 & -0.297 & -0.114 & 0.000 \\
FR & 0.023 & 0.024 & 0.033 & 0.036 & 0.030 & 0.017 & 0.005 & 0.000 \\
HN & -0.487 & -0.484 & -0.354 & -0.297 & -0.202 & -0.124 & -0.057 & 0.000 \\
PL & -0.419 & -0.418 & -0.354 & -0.297 & -0.202 & -0.124 & -0.057 & 0.000 \\
SH & -0.155 & -0.154 & -0.106 & -0.071 & -0.029 & -0.010 & -0.003 & 0.000 \\
SN & 0.300 & 0.300 & 0.257 & 0.214 & 0.133 & 0.064 & 0.017 & 0.000 \\
TY & 0.000 & 0.000 & 0.000 & 0.000 & 0.000 & 0.000 & 0.000 & 0.000 \\
Total (1) & -3.220 & -3.211 & -1.938 & -1.322 & -0.716 & -0.402 & -0.189 & 0.000 \\
Total (2) & -0.367 & -0.364 & -0.289 & -0.241 & -0.183 & -0.141 & -0.888 & 0.000 \\
Total (3) & 0.046 & 0.047 & 0.048 & 0.045 & 0.033 & 0.016 & 0.004 & 0.000 \\
\hline
\end{tabular}

Table 6 Lod scores for two point linkage of $C L / P$ and F13A1. Total lod scores with (1) autosomal dominant pattern of inheritance of $C L / P, 80 \%$ penetrance; (2) autosomal dominant pattern of inheritance of $C L / P$, penetrance $28 \%$; (3) autosomal recessive pattern of inheritance of $C L / P$, penetrance $35 \%$.

\begin{tabular}{|c|c|c|c|c|c|c|c|c|}
\hline \multirow[t]{2}{*}{ Family } & \multicolumn{8}{|c|}{$\theta$} \\
\hline & 0.000 & 0.001 & 0.05 & $0 \cdot 1$ & $0 \cdot 2$ & 0.3 & 0.4 & 0.5 \\
\hline $\begin{array}{l}\text { BR } \\
\text { CD } \\
\text { FR } \\
\text { HN } \\
\text { PL } \\
\text { SH } \\
\text { SN } \\
\text { TY }\end{array}$ & $\begin{array}{r}-0.096 \\
-2.495 \\
0.046 \\
-3.017 \\
0.000 \\
-0.454 \\
0.300 \\
-0.477\end{array}$ & $\begin{array}{r}-0.096 \\
-1.953 \\
0.046 \\
-2.675 \\
0.000 \\
-0.451 \\
0.300 \\
-0.473\end{array}$ & $\begin{array}{r}-0.076 \\
-0.461 \\
0.064 \\
-1.143 \\
0.000 \\
-0.356 \\
0.257 \\
-0.337\end{array}$ & $\begin{array}{r}-0.059 \\
-0.228 \\
0.069 \\
-0.781 \\
0.000 \\
-0.275 \\
0.214 \\
-0.241\end{array}$ & $\begin{array}{r}-0.032 \\
-0.060 \\
0.058 \\
-0.418 \\
0.000 \\
-0.149 \\
0.133 \\
-0.119\end{array}$ & $\begin{array}{r}-0.014 \\
-0.011 \\
0.032 \\
-0.233 \\
0.000 \\
-0.065 \\
0.064 \\
-0.049\end{array}$ & $\begin{array}{r}-0.003 \\
-0.001 \\
0.009 \\
-0.114 \\
0.000 \\
-0.016 \\
0.017 \\
-0.012\end{array}$ & $\begin{array}{l}0.000 \\
0.000 \\
0.000 \\
0.000 \\
0.000 \\
0.000 \\
0.000 \\
0.000\end{array}$ \\
\hline $\begin{array}{l}\text { Total (1) } \\
\text { Total (2) } \\
\text { Total (3) }\end{array}$ & $\begin{array}{r}-6.193 \\
-2.478 \\
0.223\end{array}$ & $\begin{array}{r}-5.302 \\
-2.401 \\
0.224\end{array}$ & $\begin{array}{r}-2.052 \\
-1.181 \\
0.191\end{array}$ & $\begin{array}{r}-1.301 \\
-0.710 \\
0.158\end{array}$ & $\begin{array}{r}-0.587 \\
-0.279 \\
0.097\end{array}$ & $\begin{array}{r}-0.276 \\
-0.104 \\
0.044\end{array}$ & $\begin{array}{r}-0.12 \\
-0.030 \\
0.012\end{array}$ & $\begin{array}{l}0.000 \\
0.000 \\
0.000\end{array}$ \\
\hline
\end{tabular}

Table 7 VIM allele and genotype frequencies.

\begin{tabular}{|c|c|c|c|c|c|}
\hline \multirow[t]{2}{*}{ Subject (No) } & \multicolumn{2}{|c|}{ Allele frequency } & \multicolumn{3}{|c|}{ Genotype No (\%) } \\
\hline & Al & A2 & AlAl & $\mathrm{A} 1 \mathrm{~A} 2$ & A2A2 \\
\hline $\begin{array}{l}\text { CL/P (54) } \\
\text { Control (54) }\end{array}$ & $\begin{array}{l}0 \cdot 76 \\
0 \cdot 73\end{array}$ & $\begin{array}{l}0 \cdot 24 \\
0 \cdot 27\end{array}$ & $\begin{array}{l}32(60) \\
29(54)\end{array}$ & $\begin{array}{l}18(33) \\
21(39)\end{array}$ & $\begin{array}{l}4(7) \\
4(7)\end{array}$ \\
\hline
\end{tabular}

Table 8 VIM RFLP distribution and $\chi^{2}$ analysis.

\begin{tabular}{lccccc}
\hline Enzyme & Allele & $\begin{array}{c}\text { No of CL/P } \\
\text { chromosomes }\end{array}$ & $\begin{array}{c}\text { No of control } \\
\text { chromosomes }\end{array}$ & $\chi^{2}$ & $\mathrm{p}$ \\
\hline BclI & A1 & 41 & $\begin{array}{l}39.5 \\
14.5\end{array}$ & 0.110 & $\mathrm{p}>0.5$ \\
\hline
\end{tabular}

RFLP at the RARA locus in the CL/P and control populations are presented. The RFLP distribution in cases and controls and results of the $\chi^{2}$ analysis are given in table 4 . There was no significant association with either allele at the RARA locus and the presence or absence of clefting $\left(\chi^{2}=0.954, p>0 \cdot 1\right)$.

A two point linkage analysis between RARA and the eight $\mathrm{CL} / \mathrm{P}$ families was carried out. In table 5, the lod scores resulting from an analysis testing an autosomal dominant pattern of inheritance of $C L / P$ with penetrance set at $80 \%$ are presented. Linkage was excluded between the two with a lod of $Z=-3.211$ at $\theta=0.001$ and $Z=-1.938$ at $\theta=0.05$. The other models also failed to show evidence of linkage, although they were less informative (table 5).

\section{MARKER LOCUS F13A1}

F13A1 was used in a two point linkage analysis with the eight families with $\mathrm{CL} / \mathbf{P}$. Crossovers were observed between affected subjects and F13A1 in families CD and HN. Family PL was uninformative. The lod scores for all three models are presented in table 6 . Assuming an autosomal dominant pattern of inheritance of $\mathrm{CL} / \mathrm{P}$ and penetrance of $80 \%$, linkage between F13A1 and CL/P was excluded with a lod score of $Z=-2.052$ at $\theta=0.05$.

\section{CANDIDATE LOCUS VIM}

An association analysis was carried out between polymorphisms at the vimentin locus and the presence or absence of $\mathrm{CL} / \mathrm{P}$. The allele and genotype frequencies for the $B c l I$ polymorphism at the vimentin locus in the $\mathrm{CL} / \mathrm{P}$ and control populations are presented in table 7. The distribution of the two alleles between cases and controls and results of the $\chi^{2}$ analysis are presented in table 8 . There was no significant association with either allele at the vimentin locus and the presence or absence of clefting $\left(\chi^{2}=0.110, p>0.5\right)$.

\section{MARKER LOCI D1S65 AND D1S58}

Multipoint analysis was carried out using loci D1S65 and D1S58 which flank the Van der Woude locus and the eight $\mathrm{CL} / \mathrm{P}$ families. The distance between D1S65 and D1S58 was estimated to be $15 \mathrm{cM} .{ }^{27}$ This was converted to a recombination fraction of $\theta=0.13$ using the Haldane mapping function. Crossovers between the two marker loci were observed in families $\mathrm{HN}, \mathrm{SH}, \mathrm{SN}$, and TY, while between the putative disease locus and affected subjects, crossovers were observed in families BR and $\mathrm{SH}$.

The results of the multipoint analysis, testing an autosomal dominant pattern of inheritance with $80 \%$ penetrance, are outlined in the figure. There was no evidence of linkage between $\mathrm{CL} / \mathrm{P}$ and the chromosome 1 loci with a maximum multipoint lod score of $Z=-4 \cdot 0$. A lod score of $Z=-2 \cdot 0$, which is indicative of no linkage, was found $17 \mathrm{cM}$ from D1S65 and $12 \mathrm{cM}$ from D1S58. Linkage was also 


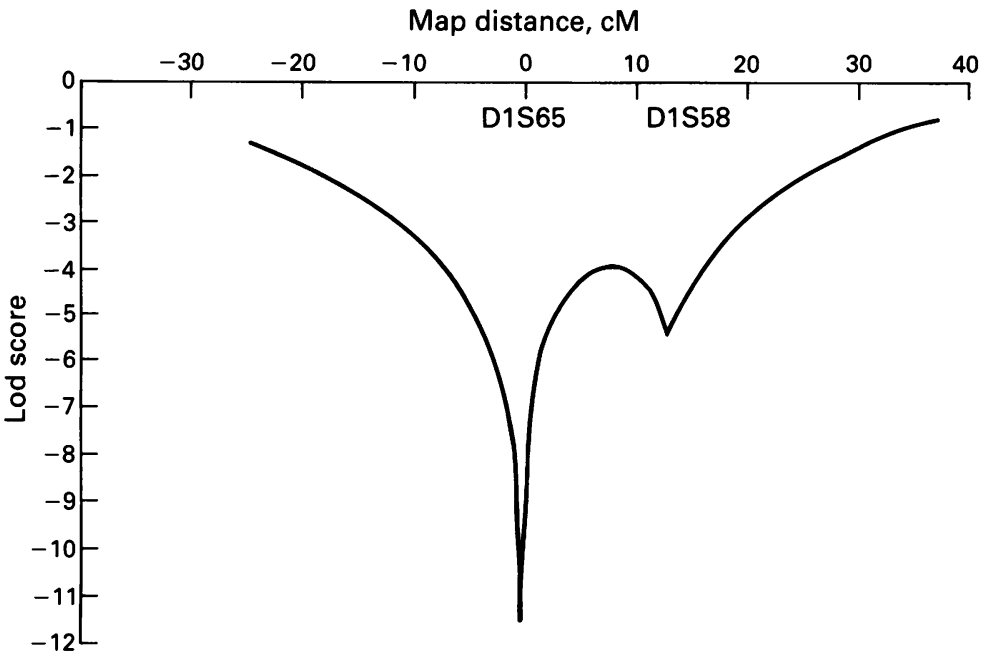

Results of multipoint analysis.

excluded using reduced penetrance $(28 \%)$ and autosomal recessive inheritance.

\section{CANDIDATE LOCUS CRTL}

CRTL1 was used in a two point linkage analysis with the eight families with $\mathrm{CL} / \mathrm{P}$ Crossovers between CRTLl and the $C L / P$ phenotype were observed in families $\mathrm{BR}, \mathrm{CD}$, FR, PL, and SH. In table 9, the lod scores are shown. There was no evidence of linkage.

\section{Discussion}

Candidates for the role of a major gene in nonsyndromic $\mathrm{CL} / \mathrm{P}$ were selected using several criteria and were tested through a combination of linkage analyses and association studies. Those loci used in a linkage approach included the markers D1S65 and D1S58, CRTL1, F13A1, and RARA. It was hoped that a significant lod score generated by any of these loci would either indicate direct involvement in familial clefting or suggest a chromosome region. Using an association approach, the loci VIM and RARA were tested for their involvement in a group of unrelated $\mathrm{CL} / \mathrm{P}$ subjects.

Contrary to the findings reported by Chenevix-Trench et al, ${ }^{10}$ there was no significant association between British $\mathrm{CL} / \mathbf{P}$ subjects and RARA polymorphisms $\left(\chi^{2}=0.954, p>0 \cdot 1\right)$. In

Table 9 Lod scores for two point linkage of CL/P and CRTL1. Total lod scores with (1) autosomal dominant pattern of inheritance of $C L / P, 80 \%$ penetrance; (2) autosomal dominant pattern of inheritance of $C L / P$, penetrance $28 \%$; (3) autosomal recessive pattern of inheritance of $C L / P$, penetrance $35 \%$.

\begin{tabular}{lrrrrrrrr}
\hline Family & \multicolumn{7}{c}{$\theta$} \\
\cline { 2 - 8 } & \multicolumn{1}{c}{0.000} & 0.001 & 0.05 & \multicolumn{1}{c}{0.1} & \multicolumn{1}{c}{0.2} & \multicolumn{1}{c}{0.3} & 0.4 & 0.5 \\
\hline BR & -2.568 & -2.054 & -0.561 & -0.314 & -0.117 & -0.040 & -0.008 & 0.000 \\
CD & -2.496 & -2.038 & -0.563 & -0.310 & -0.105 & -0.029 & -0.003 & 0.000 \\
FR & -3.176 & -2.123 & -0.517 & -0.273 & -0.086 & -0.021 & -0.002 & 0.000 \\
HN & 0.394 & 0.394 & 0.409 & 0.405 & 0.347 & 0.243 & 0.120 & 0.000 \\
PL & -2.921 & -2.495 & -0.995 & -0.697 & -0.397 & -0.222 & -0.097 & 0.000 \\
SH & -4.245 & -2.853 & -1.089 & -0.726 & -0.352 & -0.152 & -0.042 & 0.000 \\
SN & 0.823 & 0.822 & 0.740 & 0.655 & 0.483 & 0.313 & 0.150 & 0.000 \\
TY & -3.272 & -2.558 & -0.890 & -0.555 & -0.237 & -0.088 & -0.019 & 0.000 \\
Total (1) & -17.461 & -12.905 & -3.466 & -1.815 & -0.464 & 0.004 & 0.099 & 0.000 \\
Total (2) & -4.273 & -4.187 & -2.523 & -1.703 & -0.762 & -0.295 & -0.081 & 0.000 \\
Total (3) & -0.051 & -0.050 & -0.017 & 0.002 & 0.017 & 0.012 & 0.004 & 0.000 \\
\hline
\end{tabular}

the association analysis carried out by Chenevix-Trench et $a l,{ }^{10}$ the frequency of alleles among Australian $\mathrm{CL} / \mathrm{P}$ and control subjects at other candidate loci was also tested. Of the 61 British CL/P subjects, all white, who participated in the association analyses presented as part of this work, a study involving 57 of them had previously shown an association with TGFA. ${ }^{6}$ As both the Australian and British populations had shown associations with TGFA, it seemed likely that the two study groups contained persons of similar racial origin and this would be reflected in a RARA association. The apparent lack of association seen with the British $C L / P$ subjects may suggest that the association between RARA and Australian subjects with $\mathrm{CL} / \mathrm{P}$ is the result of a type I error. Replication of this work in other populations may resolve this.

Several reports have suggested the short arm of chromosome 6 as being a possible candidate region for $\mathrm{CL} / \mathrm{P}$. Eiberg et $a l^{12}$ carried out a linkage analysis which suggested linkage between $\mathrm{F} 13 \mathrm{Al}$ and the $\mathrm{CL} / \mathrm{P}$ phenotype. There have also been two reports of subjects with syndromic clefting and chromosome aberrations involving $6 \mathrm{p} 23.2829$

The possibility of a $\mathrm{CL} / \mathrm{P}$ locus within the 6p24-25 region was not confirmed in the linkage analyses carried out with F13A1 in the British families with any of the models of inheritance tested.

There is also some evidence against a gene for $\mathrm{CL} / \mathrm{P}$ within the human leucocyte antigen (HLA) region, map position $6 \mathrm{p} 21.3$. In a sib pair analysis, the segregation of HLA haplotypes in eight families with CL/P did not differ significantly from random mendelian expectation, ${ }^{30}$ ruling out linkage between HLA and $\mathrm{CL} / \mathrm{P}$ in those families.

It is possible that a gene for non-syndromic $\mathrm{CL} / \mathrm{P}$ lies distal to $6 \mathrm{p} 21.3$ and proximal to $6 \mathrm{p} 24-25$. Of the two subjects with chromosome $6 \mathrm{p} 23$ aberrations, one involved a $\mathrm{t}(6 ; 9)(\mathrm{p} 23 ; \mathrm{q} 22.3)$ translocation, ${ }^{29}$ while the other was a $6 \mathrm{p} 23$ terminal deletion. ${ }^{28}$ Both these subjects had many other clinical manifestations apart from $\mathrm{CL} / \mathbf{P}$. It is possible that the phenotype observed in the translocation subject is the result of a gene which affects other tissues in addition to the lip and palate. The syndromic clefting associated with the 6 p23 terminal deletion could result from the loss of a number of genes. This region of $6 p$ may not be a strong candidate for a major locus for non-syndromic clefting.

Vimentin is a protein belonging to the class of intermediate filaments of the cell and its synthesis occurs in tissue of mesenchymal origin. ${ }^{31}$ It was selected as a possible candidate for $\mathrm{CL} / \mathrm{P}$ based on its presence in the medial cell edge during palate fusion ${ }^{13}$ and its proximity to a translocation breakpoint in two subjects with non-syndromic CL/P. ${ }^{14}$ The results of the association study, however, suggest that vimentin does not contribute to the clefting phenotype in the unrelated British subjects analysed. There was no significant difference between the allele frequencies at VIM in subjects with 
CL/P compared with the control population $\left(\chi^{2}=0.110, p>0.5\right)$.

The markers D1S65 and D1S58 map to 1q31-32 and appear to flank the VWS locus. ${ }^{15}$ These markers were used in a multipoint analysis with the eight $\mathrm{CL} / \mathrm{P}$ pedigrees. The presence of crossovers between the two loci in four of the families reflects the estimated $15 \mathrm{cM}$ which separate these markers. ${ }^{27}$

In all three linkage models tested, there was no evidence of linkage between D1S65 and D1S58 and the CL/P phenotype, suggesting that the molecular defect underlying VWS is not the same as in non-syndromic clefting. These results are in agreement with Hecht et $a l,{ }^{32}$ who reported a lack of linkage between $\mathrm{CL} / \mathrm{P}$ and renin, to which VWS has been linked. ${ }^{15}$ One family within which cleft palate (CP) was segregating was also analysed and found not to be linked to the interval thought to contain the VWS gene.

Two other candidate genes for VWS had been considered by Murray et al. ${ }^{15}$ The first was laminin B2 (LAMB2) which is a component of the laminin molecule found in basement membranes, while the other was decay accelerating factor (DAF) which is involved in programmed cell death. Both of these were excluded as candidates for VWS owing to the occurrence of crossovers between affected subjects. LAMB2 has been mapped $8 \mathrm{cM}$ proximal to D1S65 while DAF is located $3 \mathrm{cM}$ distal to D1S58. ${ }^{27}$ From the results of the multipoint analysis presented in this study (figure), there was no evidence of linkage between these two other candidate loci and CL/P.

The polymorphic CA repeat identified within the CRTLl gene ${ }^{25}$ proved useful in a linkage analysis with the eight $\mathrm{CL} / \mathrm{P}$ families. The finding of crossovers between affected subjects in five out of eight families suggests that this locus is not involved in the $\mathrm{CL} / \mathrm{P}$ phenotype observed in these families. However, although a strongly negative lod score was generated with an autosomal dominant pattern of inheritance and $80 \%$ penetrance $(Z=-3.466$ at $\theta=0.05)$, family $S N$ alone generated a positive lod score of $Z=0.823$ at $\theta=0 \cdot 0$. CRTLl could be a gene of major effect in this family although the lod score does not reach significance.

The ability to test candidate genes or regions of chromosomes in a linkage analysis with CL/ $P$ is hampered by the scarcity of large multigeneration families. The eight families studied provided a unique opportunity to test various genes and markers under the hypothesis of a single major gene for $C L / P$. As a result of this work it is possible to conclude that there was no evidence of linkage between chromosome region 1q32, CRTL1, chromosome region 6p24-25, and RARA and a single major clefting gene in the majority of families studied. However, caution should be exercised in interpreting the results of negative linkage studies using apparently 'dominant' pedigrees segregating for $C L / P$, in view of recent studies which suggest $\mathrm{CL} / \mathrm{P}$ may be caused by multiple inter- acting loci $i^{334}$ and the difficulties in showing linkage with one locus if this were the case. ${ }^{35}$

From the population based association approach, there was no evidence of association with CL/P and VIM or RARA.

This work was generously supported by the Wellcome Trust and the Medical Research Council. Dr K K Lo was the recipient of a Hong Kong scholarship. We gratefully acknowledge the gift of probes from Dr J Dudhia, Dr R Baserga, and Professor P Chambon. We thank Paul Rutland for the synthesis of the oligonucleotide primers.

1 Marazita ML, Goldstein AM, Smalley SL, Spence MA. Cleft lip with or without cleft palate: reanalysis of a threegeneration family study from England. Genet Epidemiol 1986;3:335-42.

2 Nemana LJ, Maritza ML, Melnick M. Genetic analysis of cleft lip with or without cleft palate in Madras, India. Am f Med Genet 1992;42:5-9.

3 Temple K, Calvert M, Flint D, Thompson E, Pembrey M. Dominantly inherited cleft lip and palate in two families. f Med Genet 1989;26:386-9.

4 Hecht JT. Dominantly inherited cleft lip and palate. $\mathcal{F}$ Med Genet 1990;27:597-8.

5 Ardinger HH, Buetow KH, Bell GI, Bardach J, Van Demark DR, Murray JC. Association of genetic variation Demark DR, Murray JC. Association of genetic variation
of the transforming growth factor alpha gene with cleft lip of the transforming growth factor alpha gene with

6 Holder SE, Vintiner GM, Farren B, Malcolm S, Winter RM. Confirmation of an association between RFLPs at the transforming growth factor-alpha locus and nonsyndromic cleft lip and palate. F Med Genet 1992;29:3902 .

7 Chenevix-Trench G, Jones K, Green A, Martin N. Further evidence for an association between genetic variation in transforming growth factor alpha and cleft lip and palate. Am f Hum Genet 1991;48:1012-13.

8 Vintiner GM, Holder SE, Winter RM, Malcolm S. No evidence of linkage between the transforming growth factor-alpha gene in families with apparently autosomal dominant inheritance of cleft lip and palate. $\mathcal{F}$ Med Genet 1992;29:393-7.

9 Hecht JT, Wang Y, Blanton SH, Michels VV, Daiger SP. Cleft lip and palate: no evidence of linkage to transforming growth factor alpha. Am $\mathcal{F}$ Med Genet 1991;49:682-6.

10 Chenevix-Trench G, Jones K, Green AC, Duffy DL, Martin NG. Cleft lip with or without cleft palate: associations with the transforming growth factor alpha and retinoic acid receptor loci. Am $\mathcal{f}$ Hum Genet 1992;51:1377-85.

11 Vintiner GM, Temple IK, Middleton-Price HR, Baraitser $M$, Malcolm S. Genetic and clinical heterogeneity of Stickler syndrome. Am $\mathcal{f}$ Med Genet 1991;41:44-8.

12 Eiberg H, Bixler D, Nielsen LS, Conneally PM, Mohr J. Suggestion of linkage of a major locus for nonsyndromic orofacial cleft with F13A and tentative assignment to chromosome 6. Clin Genet 1987;32:129-32.

13 Ferguson MWJ. Palate development: mechanisms and malformations. Irish f Med Sci 1983;156:309-15.

14 Cowchock S. Apparently balanced translocations and midline defects. Am $\mathcal{f}$ Med Genet 1989;33:424.

15 Murray JC, Nishimura DY, Buetow KH, et al. Linkage of an autosomal dominant clefting syndrome (Van der Woude) to loci on chromosome 1q. Am 7 Hum Genet 1990;46:486-91.

16 Schinzel A, Klausler $M$. The Van der Woude syndrome (dominantly inherited lip pits and clefts). $\mathcal{f}$ Med Genet 1986;23:291-4.

17 Osborne-Lawrence SL, Sinclair AK, Hicks RC, et al. Complete amino acid sequence of human cartilage link protein (CRTL1) deduced from CDNA clones and chromosomal assignment of the gene. Genomics 1990;8:562-7.

18 Hascall VC. Proteoglycans: the chondroitin sulfate/keratin sulfate proteoglycan of cartilage. ISI Atlas of Science 1988;1:189-98

19 Nakamura Y, Culture M, Gillilan S, et al. Isolation and mapping of a polymorphic DNA sequence pYNZ23 to
chromosome 1 (D1S58). Nucleic Acids Res 1987;15:9620.

20 Kumlin-Wolff E, Nakamura Y, Hoff M, et al. Isolation and mapping of a polymorphic DNA sequence pEKH7.4 to chromosome 1 (D1S65). Nucleic Acids Res 1987;15:9621.

21 Marcus EM, Smith BA, Telenius $\mathrm{H}$, et al. BclI RFLP for the human vimentin gene. Nucleic Acids Res 1988;16:9068.

22 Arveiler B, Petkovich M, Mandel JL, Chambon P. A PstI RFLP for the human retinoic acid receptor in $17 \mathrm{q} 21$. Nucleic Acids Res 1988;16:6252.

23 Hecht JT, Yang P, Michels VV, Buetow KH. Complex segregation analysis of nonsyndromic cleft lip and palate. Am f Hum Genet 1991;49:674-81.

24 Chung CS, Bixler D, Watanabe T, Koguchi H, FoghAnderson P. Segregation analysis of cleft lip with or without cleft palate: a comparison of Danish and Japanese data. Am f Hum Genet 1986;39:603-11.

25 Hecht JT, Wang Y, Rhodes C, Yamada Y. GT repeat polymorphism in the human proteoglycan link gene 
(CRTL1) promoter region. Nucleic Acids Res 1991;19:6666.

26 Polymeropoulos MH, Rath DS, Xiao H, Merril CR. Tetranucleotide repeat polymorphism at the human coagulation factor XIIIA subunit gene (F13A1). Nucleic Acids Res 1991;19:4306.

27 Buetow KH, Mishimura D, Green P, Nakamura Y, Jiang $\mathrm{O}$, Murray JC. A detailed multipoint gene map of chromosome lq. Genomics 1990;8:13-21.

28 Kormann-Bortolotto MH, Farah LMS, Soares D, Corbani M, Muller R, Adell ACA. Terminal deletion 6p23: a case report. Am f Med Genet 1990;37:475-7.

29 Donnai D, Heather LJ, Sinclair P, Thakker Y, Scambler PJ, Dixon MJ. Association of autosomal dominant clef lip and palate and translocation 6p23;9q22.3. Clin Dys-

30 Van Dyke DC, Goldman AS, Spielman RS, Zmijewski $\mathrm{CM}$, Seishi O. Segregation of HLA in sibs with cleft lip or cleft lip and palate: evidence against genetic linkage. Cleft Palate f 1980;17:189-93.

31 Perreau J, Lilenbaum A, Vasseur M, Paulin D. Nucleotide sequence of the human vimentin gene and regulation of its transcription in tissues and cultured cells. Gene 1988;62:7-16.

32 Hecht JT, Wang Y, Blanton SH, Daiger SP. Van der Woude syndrome and nonsyndromic cleft lip and palate. Am f Hum Genet 1992;51:442-4.

33 Farrall M, Holder S. Familial recurrence pattern analysis of cleft lip with or without cleft palate. Am $\mathcal{f}$ Hum Genet cleft lip with or without cleft palate. Am F Hum Genet
$1992 ; 50: 270-7$.

34 Mitchell LE, Risch N. Mode of inheritance of non-syndromic cleft lip with or without cleft palate: a reanalysis. Am F Hum Genet 1992;51:323-32.

35 Farrall M, Buetow KH, Murray JC. Resolving an apparent paradox concerning the role of TGFA in $\mathrm{CL} / \mathrm{P} . A m \mathcal{F}$ Hum Genet 1993;52:434-6. 